\title{
Calcareous phytoplankton response to the half century of interannual climatic variability in Santa Barbara Basin (California)
}

\author{
Bianca De Bernardi, ${ }^{1}$ Patrizia Ziveri, ${ }^{2,3}$ Elisabetta Erba, ${ }^{1}$ and Robert C. Thunell ${ }^{4}$ \\ Received 28 May 2007; revised 24 January 2008; accepted 21 February 2008; published 4 June 2008.
}

[1] A high-resolution study of calcareous phytoplankton in a box core from the Santa Barbara Basin (SBB) reveals floral assemblage fluctuations which can be related to climatic and paleoceanographic changes during the last half century (1940-1996). In particular, Gephyrocapsa oceanica production increased during El Niño periods, in response to high temperatures, silica depletion, and increased iron availability. Conversely, Helicosphaera carteri flux increases in conjunction with lower surface temperatures associated with La Niña episodes. Increasing abundances of Florisphaera profunda and Umbilicosphaera sibogae after 1970 reflect a warming trend and increased stratification within the basin associated with the warm phase of the Pacific Decadal Oscillation (PDO). Conversely, increased abundances of Coccolithus pelagicus and Calcidiscus leptoporus before 1970 mark the cold phase of PDO. These coccolithophore production rate data are consistent with instrumental records of surface and thermocline temperatures monitored since 1950. This is the first study to document the response of calcareous phytoplankton to surface water warming occurring in SBB since 1970.

Citation: De Bernardi, B., P. Ziveri, E. Erba, and R. C. Thunell (2008), Calcareous phytoplankton response to the half century of interannual climatic variability in Santa Barbara Basin (California), Paleoceanography, 23, PA2215, doi:10.1029/2007PA001503.

\section{Introduction}

[2] High-resolution climate records are preserved in marine sediments accumulating in continental margin settings, particularly where conditions allow for the preservation of varved sediments, such as in Cariaco Basin, the Gulf of California, and Santa Barbara Basin (SBB). Such sediments are unique in providing year-to-year resolution for the past several thousand years [Hülsemann and Emery, 1961; Soutar and Crill, 1977; Biondi et al., 1997; Berger et al., 2004]. The oceanographic conditions of SBB are strongly influenced by seasonally varying winds, affecting the intensity of the California Current. However, quasiperiodic anomalies in this pattern are associated with the El Niño-Southern Oscillation. El Niño is a disruption of the ocean-atmosphere system in the tropical Pacific that has important consequences for global weather patterns. Among these consequences are increased rainfall across the southern region of the United States and in Peru, which causes destructive flooding and drought in the west Pacific. During late 1997 and early 1998 the coastal ocean off western North America was anomalously warm because of one of the strongest episodes of El Niño ever recorded [McPhaden, 1999]. Previous works on El Niño effects in

\footnotetext{
${ }^{1}$ Department of Earth Sciences “Ardito Desio," University of Milan, Milan, Italy.

${ }^{2}$ Institute of Environmental Science and Technology, Universitat Autònoma de Barcelona, Bellaterra, Barcelona, Spain.

${ }^{3}$ Department of Paleoclimatology and Geomorphology, Faculty of Earth and Life Sciences, Vrije Universiteit Amsterdam, Amsterdam, Netherlands.

${ }^{4}$ Department of Geological Sciences, University of South Carolina, Columbia, South Carolina, USA.
}

Copyright 2008 by the American Geophysical Union. 0883-8305/08/2007PA001503
SBB have shown a deepening of the thermocline, warming of surface waters, and reduced nutrient concentrations, which together alter the plankton ecosystem. For example, a significant increase in the proportion of warm water flora and fauna and a decrease in the relative contribution of siliceous microorganisms occurred during the 1997-1998 El Niño [Kincaid et al., 2000; Lange et al., 2000; Black et al., 2001].

[3] Coccolithophores form a major component of the oceanic microplankton, and they secrete calcite plates called "coccoliths." Coccoliths are mainly studied in pelagic settings where they can dominate biogenic sedimentation, but they can also constitute an important part of the phytoplankton population in high-productivity coastal zones. Several studies in upwelling areas have shown a seasonally high proportion of coccolithophore export production in these settings [Sprengel et al., 2000; Beaufort and Heussner, 2001; Andruleit et al., 2003; Boeckel and Baumann, 2004]. Coccolithophores are sensitive indicators of changes in physical-chemical properties of the surface water masses and are consequently a good proxy for longerterm climatic signals preserved in sediments [Winter and Siesser, 1994; Findlay and Giraudeau, 2002; Andruleit et al., 2004].

[4] In this paper, we quantify coccolithophore accumulation rates in the SBB in response to climatic variability. In particular, we provide a detailed reconstruction of primary production relative to two distinct climatic perturbations: El Niño and Pacific Decadal Oscillation (PDO). Most ecological changes in the eastern North Pacific associated with El Niño and the warm PDO phase are expressed as a decline in population size and biomass and/or a northward shift of some species' habitats [McGowan et al., 2003]. A study of sediment trap material from the SBB has highlighted changes in coccolithophore export production as well as 


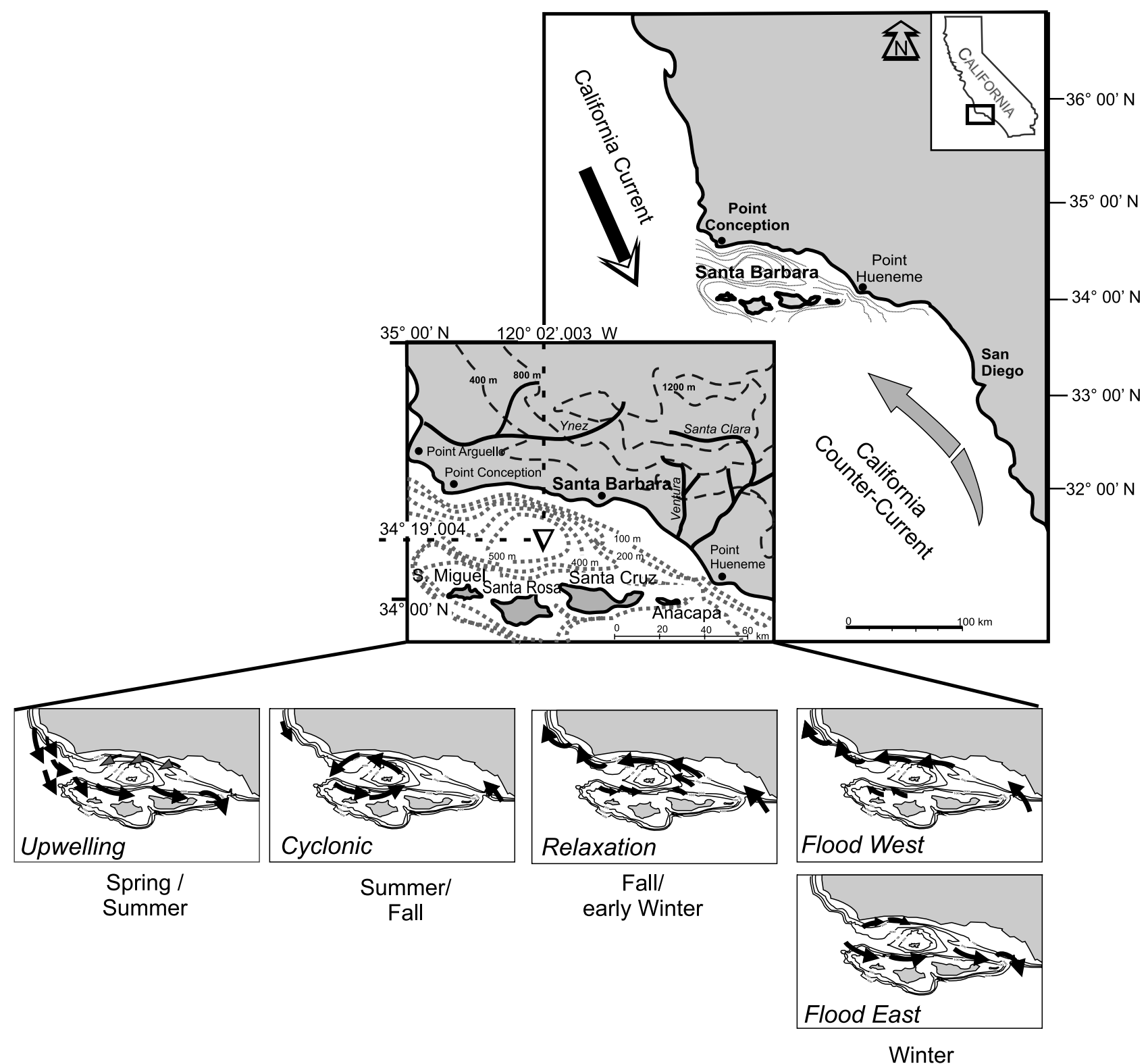

Figure 1. Bathymetric map (in meters) of SBB region and schematic representation of the large-scale oceanic flow patterns (represented by arrows; not in scale) present in the Southern California Bight. Summary of seasonal synoptic circulation pattern in SBB (from Hendershott and Winant [1996], reprinted by permission) is also reported. Location of box core SABA9610J is shown by triangle.

single-taxon changes related to the 1997-1998 El Niño [De Bernardi et al., 2005], further strengthening the suitability of coccolith fluxes and assemblages composition as paleoclimatic proxies.

[5] The long-term consequences of El Niño and influence of PDO on calcareous nannoplankton are poorly known. Consequently, the present work aims to: (1) estimate the timing and duration of assemblage variations and (2) characterize the relationships among coccolithophore assemblage, environmental variation, and changes in other plankton groups. In order to derive quasi-annual data, a high sedimentation core (SABA9610J) was sampled at high resolution for the 1940-1996 interval. Results of a sedi- ment trap study in the Santa Barbara Basin [De Bernardi et al., 2005] constitute the basis for deriving the intensity of El Niño events and PDO phases in the last 6 decades of climatic/oceanographic fluctuations. Furthermore, these coccolithophore data are key for the reconstruction of the annual climatic fluctuation in the past.

\section{Depositional and Hydrographic Conditions}

\subsection{Instrumental Hydrographic Records}

[6] The SBB is the northernmost basin of the Southern California Borderlands (Figure 1). There are two deep sills that restrict deep circulation in the basin. The first one, the 
Anacapa Sill, is located to the east between Anacapa Island and Port Hueneme (about $200 \mathrm{~m}$ depth) and separates SBB from Santa Monica Basin. The second one is located to the west of the basin (475 $\mathrm{m}$ depth) and separates it from the open ocean. These two sills limit ventilation of subsurface waters, causing dysaerobic to anoxic conditions within the deepest part of the basin. The anaerobic conditions at the seafloor drastically reduce benthic life and consequently bioturbation. Under these depositional conditions, seasonal fluctuations in sediment input are preserved as varves [Hülsemann and Emery, 1961; Reimers et al., 1990; Thunell et al., 1995]. The particulate flux in SBB is clearly controlled by strong variability in seasonal atmospheric and oceanic conditions. High terrigenous flux during fall and winter is due to increased river input associated with the rainy season [Hülsemann and Emery, 1961; Reimers et al., 1990; Thunell et al., 1995]. The Santa Clara and Ventura rivers deliver over $90 \%$ of the terrigenous sediment into $\mathrm{SBB}$, and the source rocks are mainly clastic [Fleischer, 1972]. The biogenic opal flux, mainly diatoms, is highest in spring and dominates the annual biogenic sediment flux [Lange et al., 2000; Lange et al., 1997; Thunell, 1998].

[7] Surface water circulation in the SBB results from interaction between the California Current (relatively cold and fresh) and the California Countercurrent (relatively weak and warm flow from the southern California coast) (Figure 1). The large-scale flow is generally equatorward during the spring and poleward during the summer through winter interval, although short reversals can occur [Hendershott and Winant, 1996; Auad et al., 1998]. Strong northwest winds cause intense upwelling off Point Conception year-round, although it is strongest during spring and summer (Figure 1). Highly productive waters from the upwelling flow along the SBB southern boundary and reach the Southern California Bight through the eastern SBB entrance [Hendershott and Winant, 1996]. Winters are typically mild, wet, and influenced by a weakened North American low and the migration of the North Pacific high south to $35^{\circ} \mathrm{N}$ [Huyer, 1983]. These opposite currents create complex mixing patterns, particularly in regions affected by strong eddies. These circulation features vary interannually in response to El Niño.

\subsection{El Niño and PDO Along the California Margin}

[8] Large-scale climatic forcing, like El Niño conditions in the eastern tropical Pacific Ocean, have a strong influence on the California Margin oceanographic system. El Niño events are marked by increased sea surface temperature (SST), decreased atmospheric pressure at sea level, and increased rainfall along the California Margin (Figure 2). Off California, a strong El Niño event is typically characterized by anomalously warm sea surface temperatures, reduced upwelling and flow of the California Current, and decreased productivity [Chavez et al., 2002a; McGowan, 1985; McGowan et al., 1998; Shipe and Brzezinski, 2001]. The influence of El Niño extends to higher latitudes, mostly in wintertime, and can change the jet stream and storm track locations to a more northerly location over North America [Trenberth, 1997]. In particular, the coastal ocean off western North America was anomalously warm in 1997-
1998 because of the strongest El Niño episode of the last century [McPhaden, 1999]. During this El Niño, temperature and salinity of the upper $75 \mathrm{~m}$ changed significantly, causing an increased shoreward transport of California Current water, reduction in nutrient concentrations, and increased oxygenation of bottom waters [Chavez et al., 2002a, 1999; Dever and Winant, 2002]. In particular, temperature anomalies were exceptionally large between spring 1997 and summer 1998, $\sim 4^{\circ} \mathrm{C}$ higher than the previous year [Dever and Winant, 2002]. This temperature anomaly showed maximum amplitude at the surface and decreased quickly with depth and toward the north. Another multidecadal fluctuation, the PDO, has basin-wide effects on sea surface temperature and thermocline slope that are similar to El Niño but on longer timescales.

[9] Indeed, PDO "events" persist for 20 to 30 years, while typical El Niño events persist for 6 to 18 months [Mantua et al., 1997]. The extreme events of the PDO have been classified as being either warm or cool phases, as defined by ocean temperature anomalies in the northeast and tropical Pacific Ocean. For example, a study of decadal variation in the California Current upwelling cells [Chhak and Di Lorenzo, 2007] has shown that during the warm phase of PDO, much of the upwelled water originates from a shallower depth $(<100 \mathrm{~m})$ than during the PDO cold phase $(>100 \mathrm{~m})$. Consequently, nutrient-rich deep waters are less likely to be vertically mixed to the surface during the warm phase compared to the cold one.

\section{Materials and Methods}

\subsection{Core Sampling}

[10] Sediments were collected from the dysoxic zone of the $\mathrm{SBB}\left(34^{\circ} 13^{\prime} \mathrm{N}, 120^{\circ} 03^{\prime} \mathrm{W}\right)$ using a Soutar-style box corer (SABA9610J) (Figure 1). The sediment-water interface of the core was undisturbed on the basis of the presence of bacterial mats at the sediment surface. Slabs of sediment from two subcores were X-radiographed, and the varve ages were determined by correlation to cores dated with ${ }^{210} \mathrm{~Pb}$ [Soutar and Crill, 1977; Weinheimer et al., 1999] and varve counting downward from the core top [Schimmelmann et al., 1992]. SABA9610J samples were obtained by extruding the sediment out of the acrylic tube core liner and sectioning it with a stainless steel spatula, layer by layer, as described by Schimmelmann et al. [1990].

\subsection{Coccolithophore Quantification}

[11] In the middle of each layer a subsample $(\sim 1 \mathrm{mg})$ was taken for coccolith analyses. Each subsample was oven dried at $40^{\circ} \mathrm{C}$, and the organic matter was oxidized following the procedure described by Bairbakhish et al. [1999]. Each subsample was then wet sieved under $20 \mu \mathrm{m}$ mesh, and the $<20 \mu \mathrm{m}$ fraction was filtered on Millipore filters (HTTP $0.45 \mu \mathrm{m}$ pore size, $47 \mathrm{~mm}$ diameter). A portion of the filter was mounted on a glass slide and rendered transparent with a few drops of immersion oil. For quantitative analysis of coccolithophores we used a Leitz Laborlux microscope with parallel and crossed Nicol at $1250 \times$ magnification. Coccolith accumulation rates (number coccoliths $\mathrm{cm}^{-2} \mathrm{a}^{-1}$ ) were calculated by extrapolating the counted species to the entire filter area, considering the 


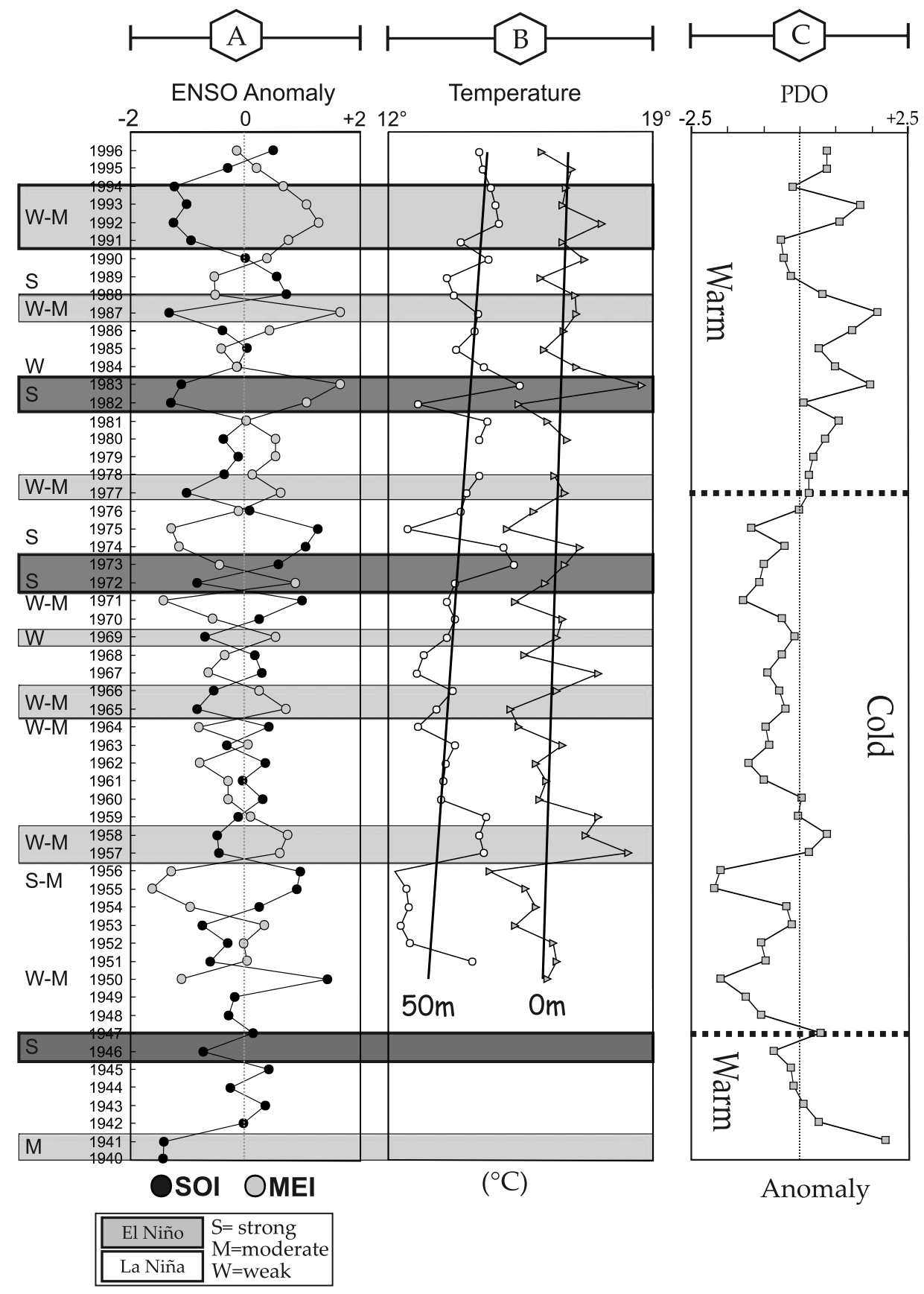

Figure 2. (a) El Niño's indexes averaged in over equatorial Pacific Ocean. The event's intensity is emphasized by shaded bars and curtailments. (b) The mean annual SSTs along California Coast at 50 and $0 \mathrm{~m}$ water depth of the California Current between $30^{\circ} \mathrm{N}, 124^{\circ} \mathrm{W}$ and $35^{\circ} \mathrm{N}, 124^{\circ} \mathrm{W}$. (c) Time series of the observed Pacific Decadal Oscillation index [Mantua et al., 1997].

sedimentation rate and the dry bulk density [Ziveri et al., 1999]. Coccoliths were counted along several parallel scans from the border toward the center of the filter for a total of $3 \mathrm{~mm}^{2}$ to ensure that the total number of counted coccoliths per sample was larger than 3000 and at least 300 specimens of the less common coccolith species $(<2 \%$ of total assemblages) were counted. The coccolith distribution on the filter was tested following work by Lototskaya [1999] and Knappertsbusch and Brummer [1995], and the deviation is $<6 \%$. Coccolithus pelagicus fluxes calculated from the sediment trap data [De Bernardi et al., 2005] were determined using the same coccolithophore quantification method described above. Taxonomy follows work by Young et al. [1997] and Young et al. [2003]. Scanning electron 
microscopy (SEM) Philips XL30 was used on selected samples to determine the taxonomy of small coccoliths not identifiable by light microscope and to document coccolith preservation.

\subsection{Geochemistry, Temperature Record, and Sediment Trap Data}

[12] Bulk inductively coupled plasma atomic emission spectrometry (ICP-AES) geochemical analyses for $\mathrm{Al}, \mathrm{Fe}$, and $\mathrm{Zn}$ were performed on the same samples used for coccolith analyses. For determination of elements mass concentration in the total and fine $(<32 \mu \mathrm{m})$ fraction, $1 \mathrm{mg}$ sample was used. The total and $<32 \mu \mathrm{m}$ elemental fluxes $\left(\mathrm{mg} \mathrm{cm}^{-2} \mathrm{a}^{-1}\right)$ were quantified by extrapolating the element concentration (ppm) to the entire effective filter area and considering the sedimentation rate. Additional details of the analytical techniques, precision, and accuracy were given by Rutten et al. [2000] and Broerse [2000].

[13] To reconstruct the water temperature, we used the interpolation between NOAA's Word Ocean Atlas [National Oceanic and Atmospheric Administration, 2005a] and California Cooperative Oceanic Fisheries Investigations (CalCOFI) (CalCOFI data are available at http://wwwmlrg.ucsd.edu) data sets. Annual average temperatures at 0 and $50 \mathrm{~m}$ were taken to generate the instrumental records presented in Figure 2.

\subsection{EI Niño and PDO Indices}

[14] There are a number of climate indices that can be used to quantify the presence and intensity of El Niño [Wolter and Timlin, 1998]. The two indices used in this study are the Multivariate El Niño Index (MEI) and the Southern Oscillation Index (SOI). MEI is based on six climate variables for the tropical Pacific (MEI data are available at http://www.cdc.noaa.gov). Sustained positive values of the MEI indicate El Niño episodes. These positive values are usually accompanied by warming of the central and eastern tropical Pacific Ocean and a decrease in the strength of the Pacific trade winds. Negative values of the MEI (La Niña) are associated with stronger Pacific trade winds and warmer sea temperatures to the north of Australia, while waters in the central and eastern tropical Pacific Ocean become cooler. Figure 2 shows the annual average pattern of MEI from 1950 through 1996.

[15] SOI is a measure of the large-scale fluctuations in air pressure difference occurring between the western and eastern tropical Pacific. Traditionally, this index has been calculated on the basis of the air pressure anomaly between Tahiti and Darwin, Australia. The negative phase of SOI represents below-normal air pressure at Tahiti and abovenormal air pressure at Darwin. Prolonged periods of negative SOI values coincide with abnormally warm ocean waters across the eastern tropical Pacific, typical of El Niño episodes. Integrating these two indices, El Niño conditions occurred 10 times between 1940 and 1996 (Figure 2), and the strength was determined from the average of the strength of chosen events (SOI data are available at http:// www.cdc.noaa.gov).

[16] The PDO index is calculated by spatially averaging the monthly SST of the Pacific Ocean north of $20^{\circ} \mathrm{N}$ [Mantua et al., 1997; Zhang et al., 1997]. The resultant phases are plotted in Figure 2 along with El Niño indexes and SST at 50 and $0 \mathrm{~m}$ water depth.

\section{Results}

\subsection{Sediment Trap Data 1996-1998}

[17] In SBB the annual coccolith assemblage is dominated by the cosmopolitan Emiliania huxleyi (80\%), followed by varying contributions by Florisphaera profunda, Gephyrocapsa oceanica, Helicospahera carteri, Calcidiscus leptoporus, Umbilicosphaera sibogae, and Coccolithus pelagicus [De Bernardi et al., 2005]. The species distribution patterns are illustrated in Figure 3 and show that high abundances of $F$. profunda and G. oceanica characterize El Niño conditions, with increases in $H$. carteri flux occurring during the non-El Niño interval. The fluxes of C. leptoporus and $C$. pelagicus show fluctuations not related to El Niño, but the flux of $C$. pelagicus was highest during the spring period of both years (Figure 3) when upwelled waters increased primary productivity in the basin.

\subsection{Down-Core Data}

\subsubsection{Abundance and Distribution Patterns of Coccolithophores}

[18] Twenty-eight coccolithophore species were identified in the sediment samples representing the 56 year period from 1940 to 1996, with eight species largely dominating the flora. Individual observations by SEM on the ring elements of small placoliths and other fragile coccoliths suggest very minor carbonate dissolution and coccolith breakage in core samples.

[19] The assemblages are dominated by E. huxleyi, which accounts for more than $85 \%$ of the total flora at all depths in the core (Figure 4). Emiliania huxleyi is followed in abundance by G. oceanica (0.4-5.3\%), Gephyrocapsa muellerae $(0.2-2.2 \%), H$. carteri $(0.3-6 \%), F$. profunda $(0.2-3 \%)$, C. leptoporus $(0.3-3.7 \%)$, U. sibogae $(0-5.2 \%)$, and $C$. pelagicus $(0-1.5 \%)$. Figures 5 and 6 document the down-core variations of the eight most abundant species. In the 56 year long study interval the total coccolith flux ranged from $5.6 \times 10^{7}(1978)$ to $58.3 \times 10^{7}$ liths $\mathrm{cm}^{-2} \mathrm{a}^{-1}(1959)$, with a mean value of $25.8 \times 10^{7}$ liths $\mathrm{cm}^{-2} \mathrm{a}^{-1}$.

[20] Emiliania huxleyi shows high fluxes during 1955, 1959, and 1971. Gephyrocapsa oceanica exhibited high fluxes during $1947\left(1.3 \times 10^{7}\right.$ liths cm $\left.\mathrm{cm}^{-2} \mathrm{a}^{-1}\right), 1958(1.0 \times$ $10^{7}$ lith cm $\left.\mathrm{cm}^{-2} \mathrm{a}^{-1}\right), 1972\left(0.9 \times 10^{7}\right.$ liths $\left.\mathrm{cm}^{-2} \mathrm{a}^{-1}\right)$, and $1983\left(1.0 \times 10^{7}\right.$ liths $\left.\mathrm{cm}^{-2} \mathrm{a}^{-1}\right)$, when the annual average SSTs exceeded $16^{\circ} \mathrm{C}$. The highest coccolith fluxes of $H$. carteri are recorded during $1967\left(1.7 \times 10^{7}\right.$ liths $\left.\mathrm{cm}^{-2} \mathrm{a}^{-1}\right)$ and $1984\left(1.7 \times 10^{7}\right.$ liths $\left.\mathrm{cm}^{-2} \mathrm{a}^{-1}\right)$. High fluxes of this species are also registered in 1951-1954, 1959, 1962 1963, and 1975, when the annual average SSTs were $<15.50^{\circ} \mathrm{C}$. Florisphaera profunda coccolith fluxes are very low from 1940 through $1967\left(1.7 \times 10^{6}\right.$ liths $\left.\mathrm{cm}^{-2} \mathrm{a}^{-1}\right)$, but after 1970 its flux increased by up to 3 times over the longterm average $\left(4.2 \times 10^{6}\right.$ liths $\left.\mathrm{cm}^{-2} \mathrm{a}^{-1}\right)$ (Figure 6) when the annual average SSTs increased $\sim 1^{\circ} \mathrm{C}$ relative to the previous 20 years. The abundance of $C$. leptoporus increased after 1947 and remained high throughout the following 20 years $\left(4.1 \times 10^{6}\right.$ liths $\left.\mathrm{cm}^{-2} \mathrm{a}^{-1}\right)$. Similar to C. leptoporus trends, the abundances of $C$. pelagicus and G. muellerae are 

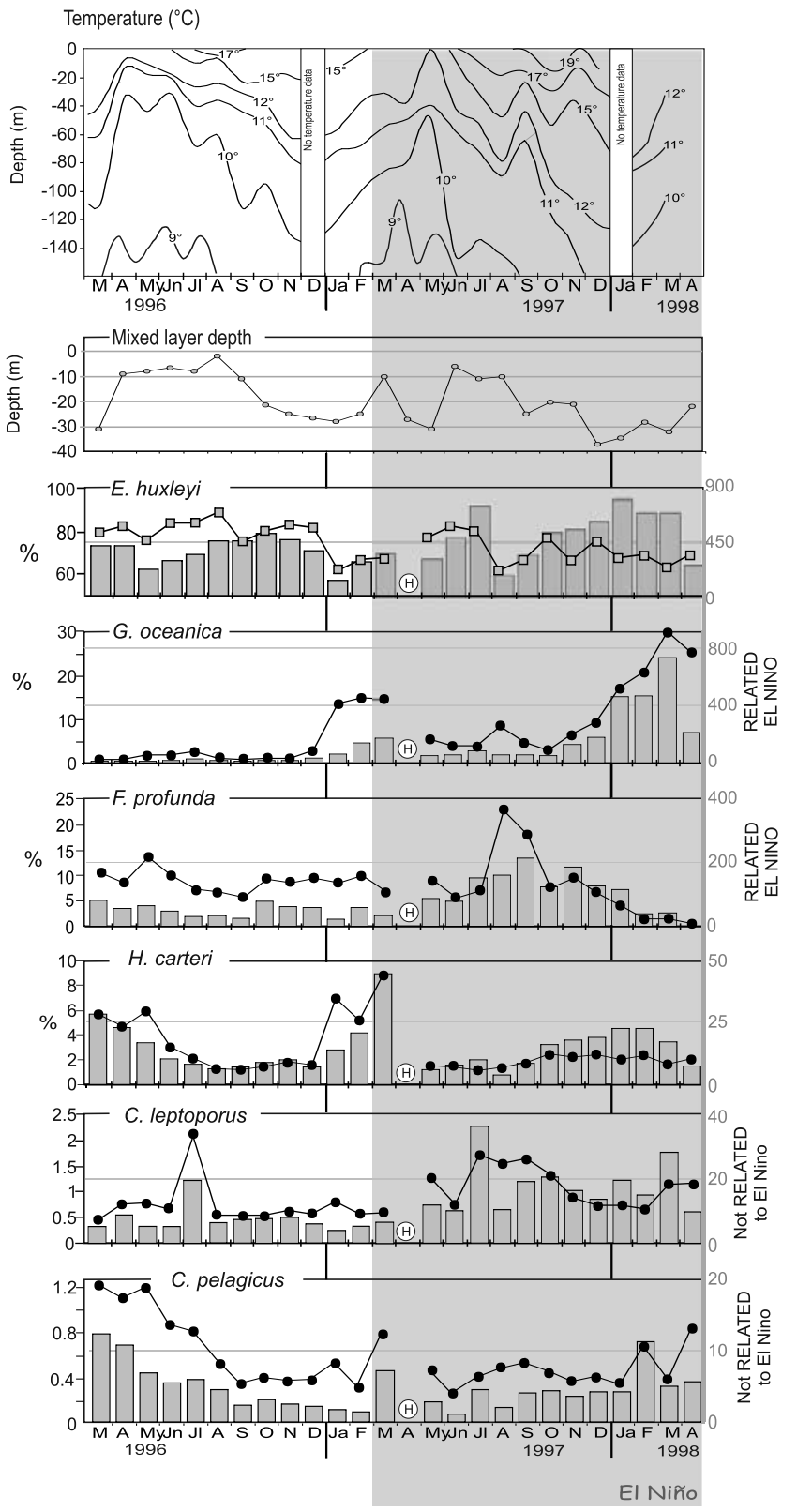

Figure 3. Temperature time series (isotherms are in degrees Celsius) for March 1996 through March 1998 based on biweekly conductivity-temperature-depth probe casts at the sediment trap mooring site. Profile of mixed layer depth measured during in SBB. Percentage (line, scale at left) and abundance (liths $\mathrm{cm}^{-2} \mathrm{~d}^{-1}$ flux bars, scale at right) of key species in the SBB during trap experiment. The El Niño phase is also indicated. $\mathrm{H}$ indicates hiatus.

generally low at the beginning of the record and then increase significantly after $1947\left(1.2 \times 10^{6}\right.$ liths $\mathrm{cm}^{-2} \mathrm{a}^{-1}$ and $2.7 \times 10^{6}$ liths $\mathrm{cm}^{-2} \mathrm{a}^{-1}$, respectively). Umbilicosphaera sibogae shows a low coccolith flux until 1977 $\left(1.1 \times 10^{6}\right.$ liths $\left.\mathrm{cm}^{-2} \mathrm{a}^{-1}\right)$, followed by significant increase $\left(2.7 \times 10^{6}\right.$ liths $\left.\mathrm{cm}^{-2} \mathrm{a}^{-1}\right)$.

\subsubsection{Elemental Analyses}

[21] Results of the bulk ICP-AES geochemical analyses are shown in Figure 5. Aluminum concentrations are 0.9$9.7 \mathrm{mg} \mathrm{cm}^{-2} \mathrm{a}^{-1}$. Fluxes of $\mathrm{Fe}$ and $\mathrm{Zn}$ vary between 1.9 and $20.1 \mathrm{mg} \mathrm{cm}^{-2} \mathrm{a}^{-1}$ and $0.1-1.3 \mathrm{mg} \mathrm{cm}^{-2} \mathrm{a}^{-1}$, respectively. All three elements show very similar trends down core. In particular, strong peaks in all three occur in 1983, 1965, and 1947. $\mathrm{Al}, \mathrm{Fe}$, and $\mathrm{Zn}$ fluxes in the fine fraction $(<32 \mu \mathrm{m})$ show the same trend as found in the total mass flux, although with a smaller amplitude. The element fluxes mirror the river discharge record, suggesting a terrigenous source from the adjacent continent.

\section{Discussion}

[22] In the sections 5.1 and 5.2 we examine the response of coccolithophores to large-scale climatic conditions in the SBB region. In particular, we highlight those species that are the best proxies for El Niño and PDO.

\subsection{Coccolithophore Response to El Niño Conditions}

[23] Physical effects of large-scale climatic forcing, such as El Niño conditions in the eastern tropical Pacific Ocean, have a strong influence on the California Current system, including anomalous surface water warming off the North American West Coast [Collins et al., 2002] and decreased primary productivity [Chavez et al., 2002a, 2002b; McGowan et al., 1998]. A main feature of El Niño conditions along the California coast is an increase in annual temperatures at all depths. For example, during the 1997-1998 El Niño, maximum surface temperatures were $2{ }^{\circ} \mathrm{C}$ higher than during the previous non-El Niño year. Moreover, the El Niño temperature anomaly extended down to $65 \mathrm{~m}$ water depth, where the maximum anomaly exceeded $5{ }^{\circ} \mathrm{C}$ [Weinheimer et al., 1999; Dever and Winant, 2002]. The climatic change associated with El Niño triggers an increase in continental input recorded in core samples as an increase in trace element fluxes (Figure 4). Chemical analyses show strong correspondence between specific elements and El Niño events; this is the case for $\mathrm{Al}, \mathrm{Fe}$, and to a lesser degree $\mathrm{Zn}$ (for example, in 1982-1983, 1962-1963, and 1946-1947). This correspondence is presumably a consequence of increased river input due to higher rainfall in this region during El Niño (Figure 4) [Thunell et al., 1995; Thunell, 1998; Johnson et al., 1999].

[24] Changes in upper ocean circulation are reflected in enhanced coccolith accumulation rates. In the sediment trap study [De Bernardi et al., 2005] the annual coccolith flux increased more than 50\% (Figure 3) during the 1997-1998 El Niño relative to the previous year. Similarly, the total coccolith flux shows a slight increase during (1983, 1978, and 1958) or just before (1972) El Niño events. The presence of warm water masses and the weakening of spring upwelling could favor production of coccolithophores over diatoms because of silica depletion. This is consistent with the work of Tozzi et al. [2004], who found that diatoms dominate under highly turbulent regimes, while coccolithophores tend to dominate under stable, nutrient-depleted conditions. On the other hand, Beaufort and Heussner [2001] found that in the Bay of Biscay, coccolith production was not dependent on diatom production because the 
a) MAJOR SPECIES

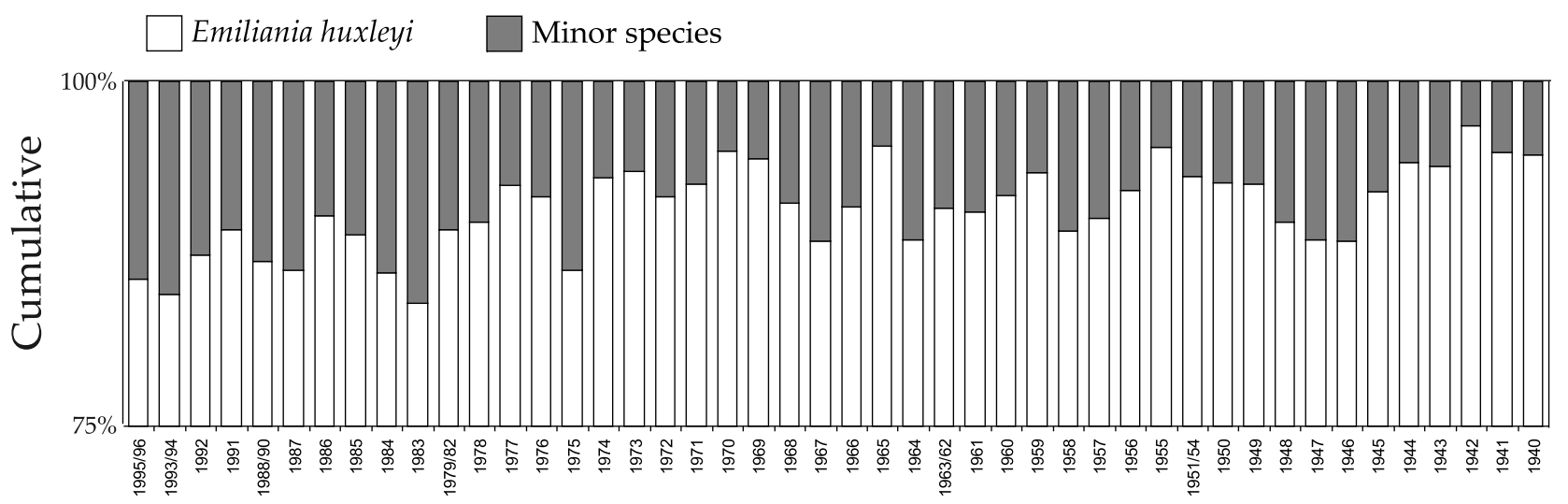

b) MINOR SPECIES

$\square$ Coccolithus pelagicus $\quad$ Gephyrocapsa oceanica $\square$ Gephyrocapsa muellerae $\quad$ Florisphaera profunda
国 Helicosphera carteri $\quad$ Umbilicosphaera sibogae $\square$ Calcidiscus leptoporus $\square$ Other

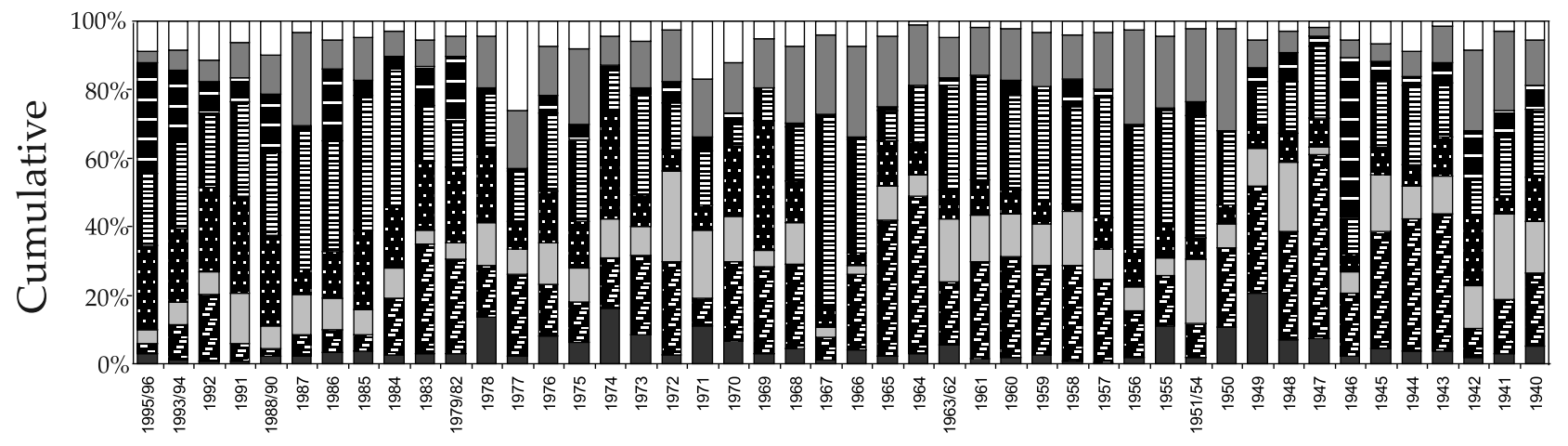

Figure 4. Relative abundance time series recorded in SABA core for (a) the Emiliania huxleyi and (b) the other seven most abundant coccolithophore species encountered in this study.

production patterns in both groups were synchronous. The duration and strength of El Niño conditions could be critical for coccolithophore export production. For example, total coccolith flux seems to vary in response to the strength of El Niño events, although the coccolith changes are often coeval with the transition "in" and "out" of the event and do not strictly correspond to El Niño conditions (Figure 5).

[25] The dominant coccolith species encountered in both trap and core sediment samples in SBB is E. huxleyi, the most abundant and ubiquitous living coccolithophore species. It is one of the most euryhaline (11-41 practical saline units) [Bukry, 1974; Winter et al., 1979] and eurythermal $\left(1-30^{\circ} \mathrm{C}\right)$ [Okada and McIntyre, 1979] species. In this study, E. huxleyi typically shows a small increase in absolute abundance at the onset of El Niño events (Figure 5). One of the common species in SBB, G. oceanica, is present throughout the non-El Niño years but shows a significant increase in absolute abundance at the onset of El Niño conditions ( $>13 \%$ more abundance than in previous year). Gephyrocapsa oceanica is known to thrive in high-nutrient environments [Mitchell-Innes and Winter, 1987; Andruleit et al., 2003] or warm marginal seas [Okada and Honjo, 1973]. This species is most abundant in the tropical Pacific between $10^{\circ} \mathrm{N}$ and $10^{\circ} \mathrm{S}$ [Roth and Coulbourn, 1982; Tanaka and Kawahata, 2001] and the Gulf of California [Ziveri and Thunell, 2000]. Moreover, in the Southern California Bight, Winter [1985] found G. oceanica associated with the poleward flowing, warm water California Countercurrent. In our SBB sediment trap study [De Bernardi et al., 2005], multiple regression analyses of environmental variables indicated that $\mathrm{Fe}$ and surface temperature (in the upper $20 \mathrm{~m}$ ) explained most of the variability in G. oceanica in SBB. Sañudo-Wilhelmy et al. [2001] have also suggested that Fe availability might 


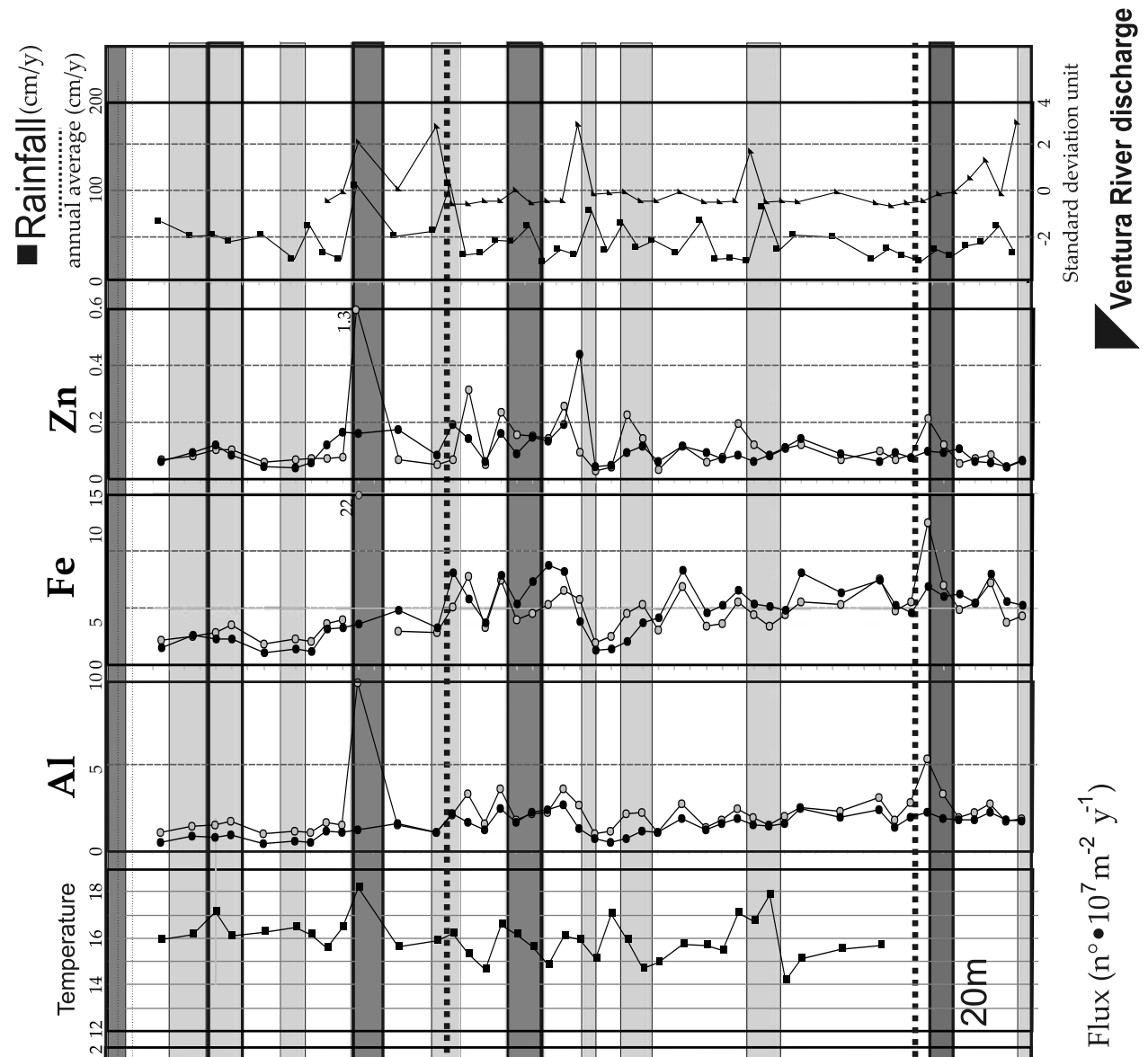

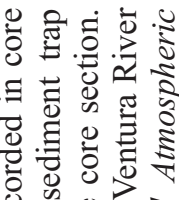

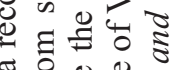

준 운

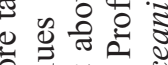

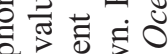

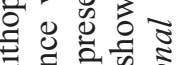

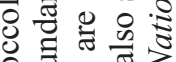

ठ है ป

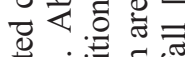

语 :

क ठ ठ

(

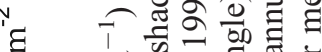

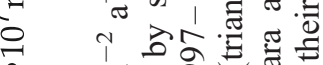

- 명

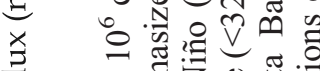

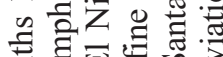

00

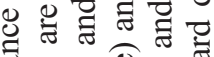

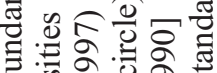

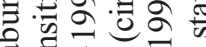

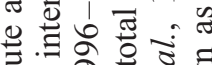

의워

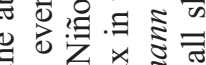

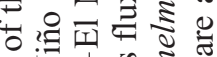

乙

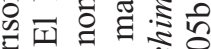

을 에는유

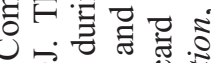

을

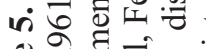

这市西

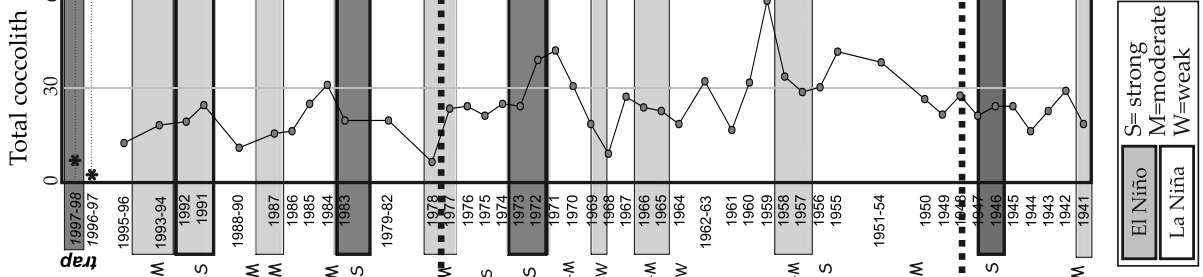

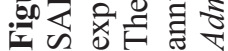

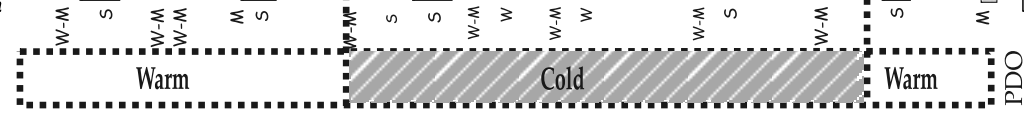




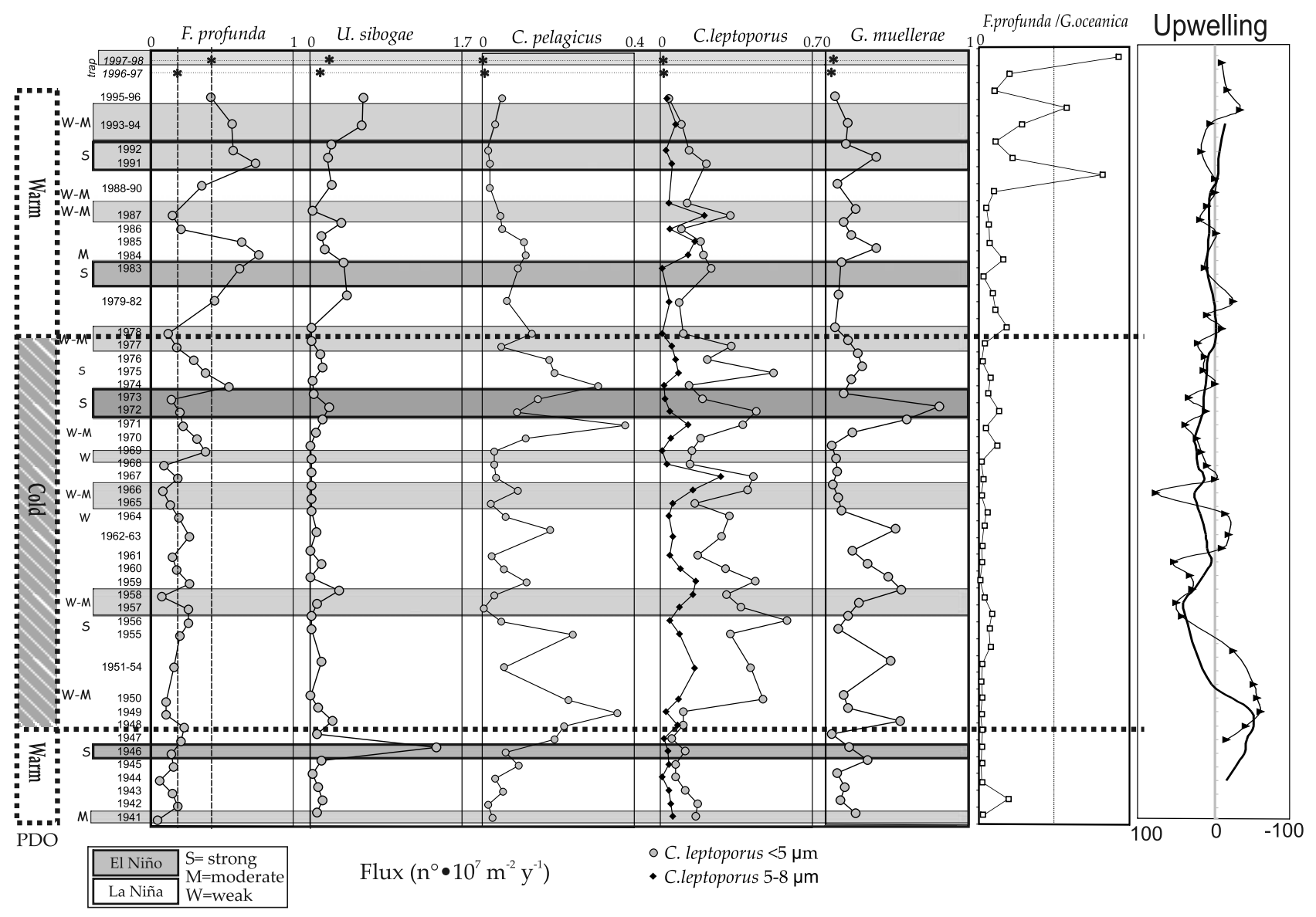

Figure 6. Comparison of the absolute abundance of selected coccolithophore taxa and $F$. profunda/G. oceanica ratio recorded in core SABA9610J. The El Niño events' intensities are emphasized by shaded bars. Value extrapolated from sediment trap experiment during non-El Niño (1996-1997) and El Niño (1997-1998) conditions are present above the core section. Time series are of annual upwelling index anomaly (in cubic meters); base period is 1946-1996, which are estimates of offshore Ekman transport driven by the alongshore geotrophic wind stress [Bograd and Lynn, 2003]. Calcidiscus leptoporus size subdivision follows work by Knappertsbusch et al. [1997] and Renaud et al. [2002].

control phytoplankton productivity in oceanic regions where surface waters are relatively rich in N and P [Martin et al., 1991; Schulz et al., 2004]. It is poorly understood what portion of available iron in seawater is readily accessible to phytoplankton, and it is still difficult to assess the fraction of iron that phytoplankton can acquire [Wells and Trick, 2004; Wells et al., 1995]. In the down-core record, G. oceanica shows an increase in its flux during the El Niño years, with peaks during the strong events in 1958, 1972, and in 1983, when Fe, Zn, and Al also increased (Figure 4). The high temperatures during El Niño events of the last decades along with increased iron availability could have triggered the production of this species (Figure 5). Extrapolating the $G$. oceanica abundance values from the sediment trap results, which included non-El Niño (19961997) and El Niño (1997-1998) conditions, it is possible to trace past changes in the occurrence and intensity of El Niño in SBB (Figure 4). El Niño events differ in strength, timing and spatial organization, and extra-tropical climatological and ecological responses. In our study, the intensity of past
El Niño events is reflected in the flux of $G$. oceanica, with maxima correlated to the strongest events $(1958,1972$, and 1983). Also, the planktonic foraminiferal and siliceous plankton fluxes show interannual variability in response to El Niño in SBB [Kincaid et al., 2000]. Lange et al. [1997] found that El Niño is generally associated with a decrease in total diatom flux in SBB. A large drop in total foraminiferal flux is restricted to the 1965 and $1982-1983$ El Niño events [Lange et al., 1990]. However, warm water planktonic foraminifera and warm water diatom species actually increase their abundance during El Niño [Weinheimer et al., 1999; Black et al., 2001].

[26] The flux of $H$. carteri increases immediately after El Niño events, when La Niña conditions develop and the SST is below $15.5^{\circ} \mathrm{C}$ (Figure 4). In particular, peaks of $H$. carteri were recorded in 1959, 1967, and 1984 when La Niña was very strong. This species has a large water temperature tolerance [Brand, 1994] and an affinity for nutrient-enriched waters [Ziveri et al., 1995a, Andruleit and Rogalla, 2002] from temperate to tropical regions [Okada and McIntyre, 
1979; Ziveri et al., 2004]. The sediment trap results show that the flux of $H$. carteri increased (Figure 3) during the spring upwelling period when colder, nutrient-rich waters enter the SBB and cause an increase in primary productivity [Lange et al., 1990]. Our down-core results indicate that this taxon thrived under La Niña conditions in SBB, presumably when cool surface waters (SSTs $<15.5^{\circ} \mathrm{C}$ ) were rich in nitrate and phosphate.

\subsection{Coccolithophore Response to Pacific Decadal Oscillation}

[27] During the past several decades, productivity in the California Current system has declined significantly for all trophic levels [Roemmich and McGowan, 1995; Lavaniegos et al., 2002]. Since the 1970s the waters off Southern California have experienced a reduction in salinity and an increase in temperature [Di Lorenzo et al., 2005]. During the same time interval, there has been a deepening of the North Pacific high [Trenberth and Hurrell, 1994]. These changes coincide with a shift from a cool phase to a warm phase of PDO. The PDO is a long-lived El Niño-like pattern of Pacific climate variability, but while the two climate oscillations have similar spatial climate fingerprints, they have very different temporal traits. The PDO phases persist for 20 to 30 years, while typical El Niño events last for 6 to 18 months. Also, the PDO climatic fingerprint is more visible in the North Pacific/North American sector than periequatorial region [Mantua et al., 1997; Hare and Mantua, 2000; Chhak and Di Lorenzo, 2007]. In SBB sediments we observe large fluctuations in total coccolith fluxes between 1954 and 1972 and a significant decrease after 1972-1973 (Figure 4). Mean flux values decrease by about $20 \%$ from $26.7 \times 10^{7}$ liths $\mathrm{cm}^{-2} \mathrm{a}^{-1}(1954-1972)$ to $21 \times 10^{7}$ liths $\mathrm{cm}^{-2} \mathrm{a}^{-1}$ during the following 20 years (1973-1996). This trend is also recorded in down-core variations of the most abundant coccolithophore species except for $F$. profunda, which undergoes an increase of up to $300 \%$ in its average coccolith flux since 1970 (Figure 5). This increase in abundance seems to record a warming of the photic zone and a gradual deepening of the thermocline since 1970. Florisphaera profunda is a tropical/subtropical species that prefers the environmental conditions within the lower photic layer between 50 and $200 \mathrm{~m}$ [Okada, 1992; Okada and Matsuoka, 1996], and its ocean distribution is controlled mainly by light transparency [Ahagon et al., 1993], temperature $\left(10-28^{\circ} \mathrm{C}\right)$ [Okada and Honjo, 1973; Cortés et al., 2001], and, to a lesser extent, nutrient availability [Cortés et al., 2001; Haidar and Thierstein, 2001]. Moreover, the relative abundance of this species has been used to reconstruct the depth of the nutricline in the equatorial Atlantic [Molfino and McIntyre, 1990] and primary productivity in the equatorial Indian Ocean [Beaufort et al., 1997]. The results of the sediment trap study [De Bernardi et al., 2005] suggest that F. profunda indeed prefers strongly stratified surface waters (thick mixed layer depth), with increased export production of this species (Figure 3) during the 1997-1998 El Niño. Consequently, the increase in $F$. profunda coccolith fluxes after 1970 may reflect enhanced stratification of surface waters and a warming of the lower photic zone. Moreover, the increase in F. profunda relative abundance may be due to a decrease in abundance of the upper photic zone taxa. This seems to be supported by the $F$. profunda/G. oceanica ratio (Figure 6) most likely reflecting the establishment of persistent surface water conditions of nutrient depauperation and strong stratification. A comparable increase in coccolith flux is also recorded by $U$. sibogae after 1977 (Figure 6). This taxon prefers oligotrophic conditions, and previous work in Southern California Bight [Winter, 1985; Ziveri et al., 1995b] indicates that this species is associated with the warm poleward flow of the California Countercurrent.

[28] In the sediment trap data, C. pelagicus increases in absolute abundance (Figure 3) during the spring when fresher and colder waters enter the basin along the Channel Islands and cause an increase in primary productivity [Lange et al., 1990]. The spring increase in C. pelagicus can be used to trace cool California Current incursions into the SBB. Recent studies [Baumann et al., 2000; Geisen et al., 2004] have shown that extant $C$. pelagicus consists of at least two distinct subspecies: the small sub-Arctic subspecies $C$. pelagicus (coccoliths $<10 \mu \mathrm{m}$ ) and the large temperate subspecies $C$. braarudii (coccoliths $>10 \mu \mathrm{m}$ ). Coccolithus pelagicus in the SBB core samples shows very little size variability (mainly coccoliths $>10 \mu \mathrm{m}$ long). The modern biogeographic distribution of $C$. pelagicus in the Pacific Ocean developed $\sim 8000$ years B.P. [Roth and Coulbourn, 1982]. This species is restricted to latitudes north of the winter $14^{\circ} \mathrm{C}$ isotherm, with a temperature range of $6-14^{\circ} \mathrm{C}$ [McIntyre et al., 1970; Roth and Coulbourn, 1982]. Coccolithus pelagicus is also known as the most calcified and dissolution resistant living species [Schneidermann, 1977; Young and Ziveri, 2000] and consequently can be transported long distances. It is also known that coccospheres of this species are well interlocked and can be preserved during sinking [Broerse, 2000; Ziveri et al., 2000]. The fact that no coccospheres of this species were found in the sinking assemblages at $500 \mathrm{~m}$ water depth in Santa Barbara suggests a different production region and lateral transport of these coccoliths. In the sediment core record, C. pelagicus coccolith fluxes increased significantly in the 1947-1977 interval, in conjunction with the cold PDO phase. During this phase, conditions along the California Margin are largely influenced by a weakened Aleutian low which favors more northerly coastal wind stress, resulting in cooler surface temperatures because of deeper upwelling [Chhak and Di Lorenzo, 2007]. The cooler surface waters lead to a less stratified surface layer and more vigorous vertical mixing.

[29] Calcidiscus leptoporus shows an increase in its coccolith flux again during the 1947-1977 interval relative to the other periods (Figure 6). In monoclonal culture studies, Quinn et al. [2003] found that C. leptoporus grown in cool water had coccospheres and coccoliths decreased in size as water temperature decreased. Calcidiscus leptoporus is a cosmopolitan coccolithophore species and has a wide morphological and genotypic variability [Quinn et al., 2004; Knappertsbusch et al., 1997; Sáez et al., 2003]. Recent plankton analyses revealed that large $C$. leptoporus cells were most abundant during nutrient-rich winter months [Renaud et al., 2002]; in contrast, Boeckel et al. [2006] 
observed that small morphotypes seem more successful in highly productive water compared to the large form. The increase in $C$. pelagicus and C. leptoporus fluxes during the cold PDO phase when upwelling is stronger confirms that these taxa favor cold, well-mixed, and productive surface waters (Figure 6). The coeval increase in G. muellerae flux is interpreted as being due to a reinvigorated influence of the California Current in the SBB, associated with the cold phase of PDO (Figure 6).

[30] The increase in abundance of the warm water coccolithophores, paralleled by a decrease in coccolith fluxes of cool water-related taxa (Figure 6) suggests changes in circulation patterns under warmer conditions (PDO warm phase). Other plankton groups also suggest a spin-down of the California Current during the last several decades [Field et al., 2006]. Lange et al. [1990] found that planktonic diatoms from SBB sediments decrease in abundance by 1 order of magnitude from 1954-1972 to 1973-1986, in association with a slower California Current. A decline in abundance of deep-living radiolarians and a decrease in foraminiferal fluxes indicates a deepening of the isopycnal surfaces over the same time period. These changes in plankton fluxes in SBB are not just local phenomena but could reflect a more widespread climatic change in the Pacific Ocean [Thunell and Mortyn, 1995; Weinheimer et al., 1999]. During warm PDO phases, SSTs tend to be anomalously cool in the central North Pacific, coincident with abnormally warm ocean temperatures along the west coast of the Americas [Francis and Hare, 1994]. This warming could be the result of a decadal scale fluctuation in ocean-atmosphere conditions [Mantua et al., 1997].

\section{Conclusions}

[31] In this study, we report the response of calcareous phytoplankton to climate changes during the period from 1940 to 1996 in the SBB, a marine ecosystem largely dominated by silica production. On the basis of the diversity and abundance of the preserved coccolithophore species, two different surface water regimes are identified in this basin. The following conclusions can be inferred.

[32] 1. The increase in G. oceanica coccolith flux in SBB provides evidence for the poleward transport of El Niño's conditions to higher latitudes. Individual El Niño events, however, differ in intensity, timing, and ecological responses. The intensity of past El Niño can be inferred from $G$. oceanica coccolith flux preserved in the sediment record, with higher values signifying stronger El Niño conditions.

[33] 2. Increases in both $C$. leptoporus and $C$. pelagicus coccolith fluxes during the cool PDO phase in SBB suggest enhancement of the North Pacific anticyclonic circulation, triggering an intensification of the California Current and an overall increase in mixing and upwelling along the California coast.

[34] 3. Conversely, F. profunda with a threefold increase in abundance after 1970 reflects the progressive warming and intensified stratification of SBB during the latter part of the 20th century. This suggests enhanced influence of warm waters in the California Current system due to a PDO warm phase. Alternately, increasing temperatures may be the result of increasing atmospheric $\mathrm{CO}_{2}$ due to anthropogenic activity. This study shows that coccolithophores directly respond to interannual (El Niño) and decadal (PDO) climate change and can be used to trace surface water temperature and stratification. Specifically, in the SBB, coccolithophore data reflect the dynamics of the California Current system forced by global climate oscillations.

[35] Acknowledgments. We would like to thank Carina Lange for access to the box core used in this study and Eric Tappa for sample analyses. We are grateful to Agostino Rizzi (CNR-IDPA) and Saskia Kars (Vrije Universiteit Amsterdam) for operating the SEM. This research was supported by the Dutch National Science Foundation (NWO), the U.S. National Science Foundation (NSF), and the Spanish Ramon y Cajal Fellowship Program. We are grateful to the anonymous reviewers (especially reviewer 1) and to Karl-Heinz Baumann for their constructive criticism and valuable suggestions.

\section{References}

Ahagon, N., Y. Tanaka, and H. Ujiie (1993), Florisphaera profunda, a possible nannoplankton indicator of late Quaternary changes in seawater turbidity at the northwestern margin of the Pacific, Mar. Micropaleontol., 22, 255273, doi:10.1016/0377-8398(93)90047-2.

Andruleit, H., and U. Rogalla (2002), Coccolithophore in surface sediments of Arabian Sea in relation to environmental gradients in surface water, Mar. Geol., 186, 505-526, doi:10.1016/S0025-3227(02)00312-2.

Andruleit, H., S. Stager, U. Rogalla, and P. Cepek (2003), Living coccolithophores in the northern Arabian Sea: Ecological tolerances and environmental control, Mar. Micropaleontol., 49, 157181, doi:10.1016/S0377-8398(03)00049-5.

Andruleit, H., U. Rogalla, and S. Stäger (2004), From living communities to fossil assemblages: Origin and fate of coccolithophores in the northern Arabian Sea, Micropaleontology, 50, 5-21, doi:10.2113/50.Suppl 1.5.
Auad, G., M. C. Hendershott, and C. D. Winant (1998), Wind-induced currents and bottomtrapped waves in the Santa Barbara Channel, J. Phys. Oceanogr., 28, 85-102, doi:10.1175/ 1520-0485(1998)028<0085:WICABT $>2.0$. $\mathrm{CO} ; 2$.

Bairbakhish, A. N., J. Bollmann, C. Sprengel, and H. R. Thierstein (1999), Disintegration of aggregates and coccospheres in sediment trap samples, Mar. Micropaleontol., 37, 219 223, doi:10.1016/S0377-8398(99)00019-5.

Baumann, K.-H., H. Andruleit, and C. Samtleben (2000), Coccolithophores in the Nordic seas: Comparison of living communities with surface sediment assemblages, Deep Sea Res. Part II, 47, 1743-1772.

Beaufort, L., and S. Heussner (2001), Seasonal dynamics of calcareous nannoplankton on a west European continental margin: The Bay of Biscay, Mar. Micropaleontol., 43, 27-55, doi:10.1016/S0377-8398(01)00020-2.
Beaufort, L., Y. Lancelot, P. Camberlin, O. Cayre, E. Vincent, F. Bassinot, and L. Labeyrie (1997), Insolation cycles as a major control of equatorial Indian Ocean primary production, Science, 278, 1451-1454, doi:10.1126/ science.278.5342.1451.

Berger, W. H., A. Schimmelmann, and C. B Lange (2004), Tidal cycles in the sediments of Santa Barbara Basin, Geology, 32, 329332, doi:10.1130/G20249.2.

Biondi, F., C. B. Lange, M. K. Hughes, and W. H. Berger (1997), Inter-decadal signals during the last millenium (AD 1117-1992) in the varve record of Santa Barbara Basin, California Geophys. Res. Lett., 24, 193-196, doi:10.1029/ 96GL03813.

Black, D. E., R. C. Thunell, and E. J. Tappa (2001), Planktonic foraminiferal response to the 1997-1998 El Niño: A sediment-trap record from the Santa Barbara Basin, Geology, 29, $1075-1078$, doi:10.1130/0091 7613(2001)029<1075:PFRTTE>2.0.CO;2. 
Boeckel, B., and K.-H. Baumann (2004), Distribution of coccoliths in surface sediments of the south-eastern South Atlantic Ocean: Ecology, preservation and carbonate contribution, Mar. Micropaleontol., 51, 301-320, doi:10.1016/ j.marmicro.2004.01.001.

Boeckel, B., K.-H. Baumann, R. Henrich, and H. Kinkel (2006), Coccolith distribution patterns in South Atlantic and Southern Ocean surface sediments in relation to environmental gradients, Deep Sea Res., Part 1, 53, $1073-$ 1099, doi:10.1016/j.dsr.2005.11.006.

Bograd, S. J., and R. J. Lynn (2003), Long-term variability in the southern California Current system, Deep Sea Res., Part II, 50, 23552370, doi:10.1016/S0967-0645(03)00131-0.

Brand, L. E. (1994), Physiological ecology of marine coccolithophores, in Coccolithophore, edited by A. Winter and W. G. Siesser, pp. 39-49, Cambridge Univ. Press, New York.

Broerse, A. (2000), Coccolithophore export production in selected ocean environments: Seasonality, biogeography, carbonate production, Ph.D. thesis, 185 pp., Vrije Univ. Amesterdam, Amsterdam.

Bukry, D. (1974), Coccoliths as paleosalinity indicators-Evidence from the Black Sea, in Black Sea-Geology, Chemistry and Biology, edited by E. T. Degens and D. A. Ross, Mem. Am. Assoc. Pet. Geol., 20, 353-633.

Chavez, F. P., P. G. Struttun, E. Friederich, R. A. Feely, G. C. Feldman, D. G. Foley, and J. M. McPhaden (1999), Biological and chemical response of the equatorial Pacific Ocean to the 1997-1998 El Niño, Science, 286, 21262131, doi:10.1126/science.286.5447.2126

Chavez, F. P., C. A. Collins, A. Huyer, and D. L. Mackas (2002a), El Niño along the West Coast of North America, Prog. Oceanogr., 54, 1-5, doi:10.1016/S0079-6611(02)00040-X.

Chavez, F. P., J. T. Pennington, C. G. Castro, J. P. Ryan, R. P. Michisaki, B. Schlining, P. Walz, K. Buck, A. McFadyen, and C. A. Collins (2002b), Biological and chemical consequences of the 1997-1998 El Niño in central California waters, Prog. Oceanogr., 54, $205-$ 232, doi:10.1016/S0079-6611(02)00050-2.

Chhak, K., and E. Di Lorenzo (2007), Decadal variations in the California Current upwelling cells, Geophys. Res. Lett., 34, L14604, doi:10.1029/2007GL030203.

Collins, C. A., C. G. Castro, H. Asanuma, T. A. Rago, S.-K. Han, R. Durazo, and F. P. Chavez (2002), Changes in the hydrography of central California waters associated with the 19971998 El Niño, Prog. Oceanogr., 54, 129147, doi:10.1016/S0079-6611(02)00046-0.

Cortés, M. Y., J. Bollmann, and H. R. Thierstein (2001), Coccolithophore ecology at the HOT station ALOHA, Hawaii, Deep Sea Res., Part II, 48, 1957-1981, doi:10.1016/S09670645(00)00165-X

De Bernardi, B., P. Ziveri, E. Erba, and R. C. Thunell (2005), Coccolithophore export production during the 1997-1998 El Niño event in Santa Barbara Basin (California), Mar. Micropaleontol., 55, 107-125, doi:10.1016/ j.marmicro.2005.02.003.

Dever, E. P., and C. D. Winant (2002), The evolution and depth structure of shelf and slope temperature and velocities during the 1997-1998 El Niño near Point Conception, California, Prog. Oceanogr., 54, 77-103, doi:10.1016/ S0079-6611(02)00044-7.

Di Lorenzo, E., A. J. Miller, N. Schneider, and J. C. McWilliams (2005), The warming of the California Current: Dynamics, thermodynamics and ecosystem implications, J. Phys.
Oceanogr., 35, 336-362, doi:10.1175/JPO2690.1

Field, D. B., T. R. Baumgartner, C. D. Charles, V. Ferreira-Bartrina, and M. D. Ohman (2006), Planktonic foraminifera of the California Current reflect 20th-century warming, Science, 311, 63-66, doi:10.1126/science.1116220.

Findlay, C. S., and J. Giraudeau (2002), Movement of oceanic fronts south of Australia during the last $10 \mathrm{ka}$ : Interpretation of calcareous nannoplankton in surface sediments from the Southern Ocean, Mar. Micropaleontol., 93, $1-14$.

Fleischer, P. (1972), Mineralogy and sedimentation history, Santa Barbara Basin, California, $J$. Sediment. Petrol., 42, 49-58.

Francis, R. C., and S. R. Hare (1994), Decadalscale regimes shifts in large marine ecosystems of the Northeast Pacific: A case for historical science, Fish. Oceanogr., 3, 279-291, doi:10.1111/j.1365-2419.1994.tb00105.x.

Geisen, M., et al. (2004), Species level variation in coccolithophores, in Coccolithophores: From Molecular Processes to Global Impact, edited by H. R. Thierstein and J. R. Young, pp. 327-365, Springer, New York.

Haidar, A. T., and H. R. Thierstein (2001), Coccolithophore dynamics off Bermuda (N. Atlantic), Deep Sea Res., Part II, 48, 1925-1956, doi:10.1016/S0967-0645(00)00169-7.

Hare, S. R., and N. J. Mantua (2000), Empirical evidence for North Pacific regime shifts in 1977 and 1989, Prog. Oceanogr., 47, 103146, doi:10.1016/S0079-6611(00)00033-1.

Hendershott, M. C., and C. D. Winant (1996), Surface circulation in the Santa Barbara Channel, Oceanography, 9, 114-121.

Hülsemann, J., and K. O. Emery (1961), Stratification in recent sediments of Santa Barbara Basin as controlled by organism and water character, J. Geol., 69, 279-290.

Huyer, A. (1983), Coastal upwelling in the California Current system, Prog. Oceanogr., 12, 259284, doi:10.1016/0079-6611(83)90010-1.

Johnson, K. S., F. P. Chavez, and G. E. Friederich (1999), Continental-shelf sediment as a primary source of iron for coastal phytoplankton, Nature, 398, 697-700, doi:10.1038/19511.

Kincaid, E., C. R. Thunell, C. B. Lange, A. L. Weinheimer, and F. M. H. Reid (2000), Planktonic foraminiferal fluxes in the Santa Barbara Basin: Response to seasonal and interannual hydrographic changes, Deep Sea Res., Part II, 47, 1157-1176.

Knappertsbusch, M., and G. J. A. Brummer (1995), A sediment trap investigation of sinking coccolithophorids in the North Atlantic, Deep Sea Res., Part I, 42, 1083-1109, doi:10.1016/ 0967-0637(95)00036-6.

Knappertsbusch, M., M. Y. Cortes, and R. H. Thierstein (1997), Morphologic variability of the coccolithophorid Calcidiscus Leptoporus in the plankton, surface sediments and from the Early Pleistocene, Mar. Micropaleontol. 30, 293-317, doi:10.1016/S0377-8398(96) $00053-9$

Lange, C. B., S. K. Burke, and W. H. Berger (1990), Biological production off southern California is linked to climatic change, Clim. Change, 16, 319-329, doi:10.1007/ BF00144507.

Lange, C. B., A. L. Weinheimer, F. M. H. Reid, and R. Thunell (1997), Sedimentation patterns of diatoms, radiolarians and silicoflagellates in Santa Barbara Basin, California, Rep. 38, pp. 161-170, Calif. Coop. Oceanic Fish. Invest., La Jolla, Calif.
Lange, C. B., A. L. Weinheimer, F. M. H. Reid, E. Tappa, and R. C. Thunell (2000), Response of siliceous microplankton from the Santa Barbara Basin to the 1997-1998 El Niño event, Rep. 41, pp. 186-193, Calif. Coop. Oceanic Fish. Invest., La Jolla, Calif.

Lavaniegos, B. E., L. C. Jiménez-Perez, and G. Gaxiola-Castro (2002), Plankton response to El Niño 1997-1998 and La Niña 1999 in the southern region of the California Current, Prog. Oceanogr., 54, 33-58, doi:10.1016/ S0079-6611(02)00042-3.

Lototskaya, A. (1999), Mid-latitude North Atlantic climate between 150,000 and 100,000 years BP, Ph.D. thesis, Vrije Univ. Amsterdam, Amsterdam.

Mantua, N. J., S. R. Hare, Y. Zhang, J. M. Wallace, and R. C. Francis (1997), A Pacific interdecadal climate oscillation with impacts on salmon production, Bull. Am. Meteorol. Soc., 78, 1069-1079, doi:10.1175/15200477(1997)078<1069:APICOW >2.0.CO;2.

Martin, J. H., R. M. Gordon, and S. E. Fitzwater (1991), The case for iron, Limnol. Oceanogr., 36, 1793-1802.

McGowan, J. A. (1985), El Niño 1983 in the Southern California Bight, Oceanus, 27, $48-51$.

McGowan, J. A., D. R. Cayan, and L.-R. M. Dorman (1998), Climate-ocean variability and ecosystem response in the northeast Pacific, Science, 281,210-217, doi:10.1126/ science.281.5374.210.

McGowan, J. A., S. J. Bograd, R. J. Lynn, and A. J. Miller (2003), The biological response to the 1977 regime shift in the California Current, Deep Sea Res., Part II, 50, 2567-2582, doi:10.1016/S0967-0645(03)00135-8.

McIntyre, A., A. W. H. Bè, and M. B. Roche (1970), Modern Pacific coccolithophorida: A paleontological thermometer, Trans. N. Y. Acad. Sci., 32, 720-731.

McPhaden, M. J. (1999), Genesis and evolution of the 1997-98 El Niño, Science, 283, 950953, doi:10.1126/science.283.5404.950.

Mitchell-Innes, B. A., and A. Winter (1987), Coccolithophores: A major phytoplankton component in mature upwelled waters off the Cape Penisula, South Africa, Mar. Biol., 95, 25-30, doi:10.1007/BF00447481

Molfino, B., and A. McIntyre (1990), Processional forcing of nutricline dynamics in the equatorial Atlantic, Science, 249, 766-769, doi:10.1126/science. 249.4970 .766

National Oceanic and Atmospheric Administration (2005a), World Ocean Atlas, http:// www.nodc.noaa.gov, Natl. Oceanogr. Data Cent., Silver Spring, Md.

National Oceanic and Atmospheric Administration (2005b), National Environmental Satellite Data, and Information Service, http:// lwf.ncdc.noaa.gov/oa/ncdc.html, Natl. Clim. Data Cent., Boulder, Colo.

Okada, H. (1992), Biogeography control of modern nannofossil assemblages in surface sediments of Ise Bay, Mikawa Bay and KumanoNada, off coast of Central Japan, Mem. Sci. Geol., 43, 431-449.

Okada, H., and S. Honjo (1973), The distribution of oceanic coccolithophorids in the Pacific, Deep Sea Res., Part II, 20, 355-374.

Okada, H., and S. Honjo (1975), Distribution of coccolithophores in marginal seas along the western Pacific Ocean and Red Sea, Mar Biol., 31, 271-285, doi:10.1007/BF00387154. Okada, H., and A. Matsuoka (1996), Lowerphotic nannoflora as indicator of the late Quaternary monsoonal paleo-record in the tropical 
Indian Ocean, in Microfossils and Oceanic Environments, edited by A. Moguilevsky and R. Whatley, Cambrian, Aberystwyth, UK.

Okada, H., and A. McIntyre (1979), Seasonal distrubution of modern coccolithophores in the western North Atlantic Ocean, Mar. Biol., 54, 319-328, doi:10.1007/BF00395438.

Quinn, P., H. R. Thierstein, L. Brand, and A. Winter (2003), Experimental evidence for the species character of the Calcidiscus leptoporus morphotypes, J. Paleontol., 77, 825-830, doi:10.1666/ 0022-3360(2003)077<0825:EEFTSC $>2.0$. $\mathrm{CO} ; 2$.

Quinn, P. S., A. Saez, K.-H. Baumann, B. A. Steel, and C. Sprengel (2004), Coccolithophorid biodiversity: Evidence from the cosmopolitan species Calcidiscus leptoporus, in Coccolithophores: Molecular Processes to Global Impact, edited by H. R. Thierstein and J. R. Young, pp. 299-236, Springer, New York.

Reimers, C. E., C. B. Lange, M. Tabak, and J. M. Bernahard (1990), Seasonal splillover and varve formation in the Santa Barbara Basin, California, Limnol. Oceanogr., 35, 15771585.

Renaud, S., P. Ziveri, and A. T. C. Broerse (2002), Geographical and seasonal difference in morphology and dynamics of the coccolithophore Calcidiscus leptoporus, Mar. Micropaleontol., 46, 363-385, doi:10.1016/S0377-8398(02)00081-6.

Roemmich, D., and J. McGowan (1995), Climatic warming and the decline of zooplankton in the California Current, Science, 267, 13241326, doi:10.1126/science.267.5202.1324

Roth, P. H., and W. T. Coulbourn (1982), Floral and solution patterns of coccoliths in surface sediments of the North Pacific, Mar. Micropaleontol., 7, 152, doi:10.1016/0377-8398(82)90014-7.

Rutten, A., G. J. de Lange, P. Ziveri, J. Thomson, P. J. M. van Santvoort, S. Colley, and C. Corselli (2000), Recent terrestrial and carbonate fluxes in the pelagic eastern Mediterranean; a comparison between sediment trap and surface sediment, Palaeogeogr. Palaeoclimatol. Palaeoecol., 158, 197-213, doi:10.1016/ S0031-0182(00)00050-X.

Sáez, A. G., I. Probert, P. Quinn, J. R. Young, and L. K. Medlin (2003), Pseudo-cryptic speciation in coccolithophores, Proc. Natl. Acad. Sci. U.S.A., 100(12), 7163-7168

Sañudo-Wilhelmy, S. A., A. B. Kustka, C. J. Gobler, D. A. Hutchins, M. L. K. Yang, J. Burns, D. G. Capone, J. A. Raven, and E. J. Carpenter (2001), Phosphorus limitation of nitrogen fixation by Trichodesmium in the central Atlantic Ocean, Nature, 411, 66-69, doi:10.1038/ 35075041 .

Schimmelmann, A., C. B. Lange, and W. H. Berger (1990), Climatically controlled marker layers in Santa Barbara Basin sediments and fine-scale core-to-core correlation, Limnol. Oceanogr., 35, 165-173.

Schimmelmann, A., C. B. Lange, W. H. Berger, A. Simon, S. K. Burke, and R. B. Dunbar (1992), Extreme climatic conditions recorded in Santa Barbara laminated sediments: The 18351840 Macoma event, Mar. Geol., 106, 279-299, doi:10.1016/0025-3227(92)90134-4.

Schneidermann, N. (1977), Selective dissolution of recent coccoliths in the Atlantic Ocean, in
Oceanic Micropalaeontology, edited by A. T. S. Ramsey, pp. 973-1008, Elsevier, London.

Schulz, K. G., I. Zondervan, L. J. A. Gerringa, K. R. Timmermans, M. J. W. Veldhuis, and U. Riebesell (2004), Effect of trace metal availability on coccolithophorid calcification, Science, 430, 673-676.

Shipe, R. F., and M. A. Brzezinski (2001), A time series study of silica production and flux in an eastern boundary region: Santa Barbara Basin, California, Global Biogeochem. Cycles, 15, 517-531, doi:10.1029/2000GB001297.

Soutar, A., and P. A. Crill (1977), Sedimentation and climatic patterns in the Santa Barbara Basin during the 19th and 20th centuries, Geol. Soc. Am. Bull., 88, 1161-1172, doi:10.1130/ 0016-7606(1977)88<1161:SACPIT > 2.0.CO;2.

Sprengel, C., K.-H. Baumann, and S. Neuer (2000), Seasonal and interannual variation of coccolithophore fluxes and species compositions in sediment traps north of Gran Canaria $\left(29^{\circ} \mathrm{N} 15^{\circ} \mathrm{W}\right)$, Mar. Micropaleontol., $39,157-$ 178, doi:10.1016/S0377-8398(00)00019-0.

Tanaka, Y., and H. Kawahata (2001), Seasonal occurrence of coccoliths in sediment traps from West Caroline Basin, equatorial West Pacific Ocean, Mar. Micropaleontol., 43, $273-$ 284, doi:10.1016/S0377-8398(01)00027-5.

Thunell, R. (1998), Particle fluxes in a coastal upwelling zone: Sediment trap results from Santa Barbara Basin, California, Deep Sea Res., Part II, 45, 1863-1884, doi:10.1016/ S0967-0645(98)80020-9.

Thunell, R. C., and P. G. Mortyn (1995), Glacial climate instability in the northeast Pacific Ocean, Nature, 376, 504-506, doi:10.1038/ $376504 \mathrm{a} 0$.

Thunell, R. C., E. Tappa, and D. M. Anderson (1995), Sediment fluxes and varve formation in Santa Barbara Basin, offshore California, Geology, 23, 1083-1086, doi:10.1130/00917613(1995)023<1083:SFAVFI>2.3.CO;2.

Tozzi, S., O. Schofield, and P. Falkowski (2004), Historical climate change and ocean turbulence as selective agents for two key phytoplankton functional groups, Mar. Ecol. Prog. Ser., 274, 123-132, doi:10.3354/meps274123.

Trenberth, K. E. (1997), The definition of El Niño, Bull. Am. Meteorol. Soc., 78, 27712777, doi:10.1175/1520-0477(1997)078 $<2771$ :TDOENO $>2.0$. CO; 2

Trenberth, K. E., and J. W. Hurrell (1994), Decadal atmosphere-ocean variations in the Pacific, Clim. Dyn., 9, 303-319, doi:10.1007/ BF00204745.

Weinheimer, A. L., D. R. Cayan, and J. P. Kennett (1999), Recent increase in surface-water stability during warming off California as recorded in marine sediments, Geology, 27, 1019-1022 doi:10.1130/0091-7613(1999)027< 1019:RIISWS $>2.3$. CO;2.

Wells, M. L., and C. G. Trick (2004), Controlling ron availability to phytoplankton in iron-replete coastal waters, Mar. Chem., 86, 1-13, doi:10.1016/j.marchem.2003.10.003.

Wells, M. L., N. M. Price, and K. W. Bruland (1995), Iron chemistry in seawater and its relationship to phytoplankton: A workshop report, Mar. Chem., 48, 157-182, doi:10.1016 0304-4203(94)00055-I.

Winter, A. (1985), Distribution of living coccolithophores in the California Current sys- tem, southern California borderland, Mar Micropaleontol., 9, 385-393, doi:10.1016/ 0377-8398(85)90007-6.

Winter, A., and W. G. Siesser (1994), Coccolithophore, 242 pp., Cambridge Univ. Press, New York.

Winter, A., Z. Reiss, and B. Luz (1979), Distribution of living coccolithophore assemblages in the Gulf of Elat ('Aqaba), Mar. Micropaleontol., 4, 197-223, doi:10.1016/03778398(79)90017-3.

Wolter, K., and M. S. Timlin (1998), Measuring the strength of ENSO events: How does $1997 /$ 98 rank?, Weather, 53, 315-324.

Young, R. J., and P. Ziveri (2000), Calculation of coccolith volume and its use in calibration of carbonate flux estimates, Deep Sea Res., Part II, 47, 1679-1700, doi:10.1016/S09670645(00)00003-5.

Young, R. J., J. A. Berger, P. R. Bown, J. A. Burnett, A. Fiorentino, R. W. Jordan, A. K Kleijne, B. E. Van Niel, A. J. Ton Romein, and K. von Salis (1997), Guidelines for the coccolith and calcareous nannofossil terminology, Palaeontology, 40, 875-912.

Young, R. J., M. Geisen, L. Cros, A. Kleijne, C. Sprengel, I. Probert, and J. Ostergaard (2003), A Guide to Extant Coccolithophore Taxonomy, 125 pp., Int. Nannoplankton Assoc., London.

Zhang, J., J. M. Wallace, and D. S. Battisti (1997), ENSO-like interdecadal variability: 1900-93, J. Clim., 10, 1004-1020, doi:10.1175/15200442(1997)010<1004:ELIV>2.0.CO 2 .

Ziveri, P., and R. C. Thunell (2000), Coccolithophore export production in Guaymas Basin, Gulf of California: Response to climate forcing, Deep Sea Res., Part II, 47, 2073-2100.

Ziveri, P., R. C. Thunell, and D. Rio (1995a), Export production of coccolithophore in an upwelling region: Results from San Pedro Basin southern California, Mar. Micropaleontol., 24 , 335-358, doi:10.1016/0377-8398(94)00017-H.

Ziveri, P., R. C. Thunell, and D. Rio (1995b), Seasonal changes in coccolithophore densities in the Southern California Bight during 1991 1992, Deep Sea Res., Part I, 42, 1881-1903.

Ziveri, P., J. R. Young, and J. E. Van Hinte (1999), Coccolithophore export production and accumulation rates, GeoResearch Forum $5,41-56$.

Ziveri, P., A. Broerse, J. E. van Hinte, P. Wesbroek, and S. Honjo (2000), The fate of coccoliths a $48^{\circ} \mathrm{N} 21^{\circ} \mathrm{W}$, northeastern Atlantic, Deep Sea Res., Part II, 47, 1853-1875, doi:10.1016/ S0967-0645(00)00009-6.

Ziveri, P., K.-H. Baumann, B. Bockel, J. Bollmann, and J. R. Young (2004), Biogeography of selected Holocene coccoliths in the Atlantic Ocean, in Coccolithophores: From Molecular Processes to Global Impact, edited by H. R Thierstein and J. R. Young, pp. 403-428, Springer, New York.

B. De Bernardi and E. Erba, Department of Earth Sciences "Ardito Desio," University of Milan, Via Mangiagalli 34, I-20133, Milano, Italy. (bianca.debernardi@unimi.it)

R. C. Thunell, Department of Geological Sciences, University of South Carolina, Columbia, SC 29208, USA.

P. Ziveri, Institute of Environmental Science and Technology, Universitat Autònoma de Barcelona, E-08193 Bellaterra, Barcelona, Spain. 